\title{
MEMBANGUN KEBIJAKAN PUBLIK UNGGUL DI ERA DEMOKRASI
}

\author{
Oleh: \\ Riant Nugroho \\ riantnd@gmail.com \\ Dosen Magister Ilmu Pemerintahan \\ Universitas Jenderal Achmad Yani
}

\begin{abstract}
The superiority of a nation is increasingly determined by the Government's ability of the nation to produce superior policies. The era of Indonesian democracy since the 1998 Reformation has not yet promised a public policy blow. The question is how to build capacity to build superior public policy. The answer is offered in the form of Ten Principles (also called "Laws") of Public Policy. They are -Publicll, - A Point of No Returnll, -Great, not Good\|, -Management, not politics\|, -Moral, not technicall, -A system, not units\|, -A Gift\|, -Honor\|, -Glorify', and-Learning $\|$. The performing policy in various places, at various times, in various governments were cored on the principles, and it will be in the next future.
\end{abstract}

\section{Keyword : Excellence Nation, Excellence Policy, Ten Principles}

\section{Agenda}

Pertanyaan yang hendak kita jawab adalah bagaimana kita kebijakan publik di era demokrasi, dan kebijakan publik yang bagaimana yang perlu kita bangun pada era demokrasi, untuk memperkuat demokrasi, membuat demokrasi semakin sehat dan bernilai bagi bangsa. Ini menjadi sebuah pertanyaan genting, karena demokrasi di negara-negara berkembang sedang mengalami -tantangan\|, karena demokrasi yang berkembang berubah menjadi ologarki baru, bukan saja oleh partai-partai, tetapi para kaya, sehingga dari bentuk bernama demokrasi, namun isinya adalah plutokrasi. Namun, demokrasi, tetap menjadi pilihan sistem politik terbaik, masalahnya bagaimana kita menjadikan yang baik tersebut benar-benar baik.

Suatu negara yang berada dalam masalah yang berat biasanya mempunyai empat gejala yang terjadi bersamaan: ekonominya kalah karena semakin tergantung kepada negara lain, pemimpinnya terbelah menjadi faksi-faksi yang berkelahi tanpa alasan yang masuk akal dan manusiawi, rakyatnya mendadak menjadi pemarah dan media sosial mempercepat akumulasi kemarahan tersebut, dan alam semakin berubah dalam rupa bencana yang luar biasa sebagai akibat kerusakan lingkungan yang akut. Penyebab utamanya adalah, karena tidak menyadari, bahwa sempat rangkaian gejala 
tersebut bukanlah sesuatu yang tiba-tiba, melainkan disebabkan oleh kebijakankebijakan yang dibuat oleh Pemerintah negara tersebut. Alhasil, manajemen negara tersebut sudah masuk mode -PANIK\| karena disokong oleh strategi yang penuh emosi akibat kebijakan yang implusif, apa yang dilihat, langsung dibuat kebijakan diputuskan waktu itu juga.

Thomas R. Dye (2016) memberikan definisi kebijakan publik yang baik, yaitu - whatever governments choose to do or not do...It is what government do, why they do it, and what difference it makes $\|^{1}$. Tepat sekali, kebijakan publik adalah pilihan dan nilai yang diberikan atas pilihan itu. Dan, yang membuat pilihan bukan rakyat, tetapi pemerintah. Dari sini, saya memulai pemahaman kebijakan publik sebagai seperangkat keputusan-keputusan strategis untuk memanajemeni kehidupan suatu bangsa untuk mencapai misi pembentukannya, yang biasanya dimuskan oleh pada pendirinya -the founding fathers - dalam bentuk Konstitusi atau Undang-Undang Dasar.

Sebagai sebuah strategi, kebijakan publik ada pada semua bangsa dengan sistem politik yang berbeda. Mulai bangsa primitif dengan sistem politik yang otoriter, bangsa agraris tradisional dengan sistem politik paternalistik, bangsa di abad pertengahan dengan sistem politik monarkhi absolut, bangsa modern dengan sistem politik demokratis, mulai dari demokrasi liberal di Amerika Serikat dan Inggris, demokrasisosialis di Belanda, Jerman, dan Skandinavia, hingga demokrasi-khas, seperti demokrasi Pancasila di Indonesia, kesemuanya mempunyai kebijakan publik.

Kebijakan publik adalah seperangkat keputusan politik yang melembaga dari suatu kekuasaan politik yang sah. Keputusan-keputusan politik tersebut berkenaan dengan alokasi-alokasi sumberdaya penting dan langka pada bangsa tersebut, untuk memastikan agar penggunaan atau pemanfaatannya untuk kebaikan bangsa tersebut, bukan justru untuk merusak, apalagi menghancurkan. Kebijakan publik adalah keputusan alokasi sumberdaya untuk memastikan pendayagunaannya memberikan kebaikan bagi bangsa tersebut, dan bukan yang lain, apalagi sebaliknya. Bahkan, bagi bangsa-bangsa dan organisasi-organisasi supra-negara dengan kiprah yang mendunia, maka seperangkat kebijakan publik dibuat untuk memastikan setiap alokasi sumberdaya penting dan terbatas (atau langka), dijamin untuk memberikan kebaikan kepada umat manusia.

\footnotetext{
${ }^{1}$ Thomas R. Dye, 2016, Understanding Public Policy (15th Edition), New York: Pearson.
} 
Tentu saja, dalam prinsip yang dalam teori evolusi Charles Darwin disebut sebagai survival for the fittest, maka terdapat sejumlah kekuasaan negara yang membuat kebijakan publik untuk menguasai bangsa-bangsa lain di luar bangsa, baik untuk kepentingan bangsa mereka sendiri, maupun untuk kepentingan pribadi atau kelompok mereka. Kolonialisasi atau penjajahan bangsa-bangsa atas bangsa-bangsa lain, baik di jaman Kuno, Awal, Pertengahan, Pencerahan, Modern, hingga saat ini, adalah salah satu bentuk kebijakan publik. Pertanyaanya adalah, apakah itu sesuai dengan Konstitusi mereka.

Pertama, mungkin karena konstitusinya identik dengan Perintah Raja, Kaisar, Sultan atau Penguasa yang mereka miliki, atau juga karena mereka memahaminya demikian. Dari sini, kita dapat mengelompokkan dua jenis konstitusi, yaitu yang agresif dan pasif. Di kelompok agresif terdapat kelompok yang posesif dan kelompok yang ekspansionistik. Di kelompok pasif, terdapat kelompok yang harmonis ada yang naif. Meski demikian, saya juga memberi label dua kelompok -agresif dan pasif - sebagai kelompok konstitusi yang extrovert dan yang intravert. Terlepas dari karakter konstitusinya, kebijakan publik tetaplah sebagai seperangkat keputusan keputusan untuk mengalokasikan sumberdaya penting dan terbatas pada suatu bangsa untuk memastikan pendayagunaannya memberikan kebaikan bagi bangsa tersebut. Dengan demikian, kita memasuki pemahaman ke dua kebijakan publik, yaitu sebagai sebuah strategi.

Kebijakan publik adalah strategi untuk memanajemeni bangsa dalam mencapai tujuan hidup berbangsa. Sebagai sebuah strategi, kebijakan publik menjadi keharusan dari semua organisasi negara, -tidak pedulul bagaimana bentuk negaranya. Entah negara maju, berkembang, ataupun terbelakang; negara di -dunia pertamall maupun di -dunia ke tigall. Sebagai strategi, maka kebijakan publik mempunyai definisi sebagai sebuah strategi untuk membawa suatu bangsa dari suatu kondisi pada saat ini, untuk mencapai suatu kondisi tertentu, yang jauh lebih baik dari hari ini, di suatu ketika di masa depan. Kebijakan publik adalah sebuah teknologi untuk membawa -masa depan ke hari inill.

Mari kita meletakkan diri sebagai pemimpin suatu bangsa. Pertama, sebagai Kepala Daerah, maka kebijakan publik yang dibuat oleh Pemerintah Daerah, yang disahkan oleh Kepala Daerah, adalah membawa rakyat daerah suatu negara menjadi rakyat daerah di negara yang sama dengan kondisi sosial, ekonomi, dan kebudayaan yang jauh lebih tinggi dari sebelumnya; sebuah kondisi yang membuat rakyat di daerah 
tersebut bangga kepada diri dan komunitasnya; bahkan, pada tingkat tertentu membuatnya bangga dengan Pemerintah Daerah dan Kepala Daerah. Karena itu, di daerah diperlukan kebijakan untuk memastikan ketersediaan pangan, ketersediaan sandang, ketersediaan tempat tinggal, disusul ketesediaan pekerjaan, kesempatan berusaha, keamanan, keadilan, dan akhirnya kesejahteraan untuk semua, dengan cara mengalokasikan sumberdaya penting dan terbatas di daerah tersebut kepada warga daerah sedemikian rupa sehingga pemanfaatannya memberikan kemanfaatan yang sebesar-besarnya untuk semua. Pemerintah Indonesia menemukan 5 gubernur, 12 bupati, dan 7 wali kota yang terbaik pada tahun 2017, dan memberikan penghargaan Leadership Award $2017^{2}$. Saya beruntung pernah bertemu dan berdiskusi dengan beberapa dari mereka, yaitu Dr. Sukarwo dan Abdullah Azwar Anas, dan memang mereka adalah pejabat pemegang kekuasaan puncak di daerah yang mengerti kebijakan publik sebagai sebuah strategi. Meski, tentu saja, ada beberapa kepala daerah yang sebenarnya tidak mencapai kriteria yang dimaksud di sini.

Bagaimana dengan Menteri? Jika kita adalah seorang Menteri pada suatu kabinet pemerintahan, maka kebijakan publik yang kita buat merupakan strategi untuk membawa rakyat pada sektor kegiatan yang kita bawahi, baik sebagai manusiamanusia maupun sebagai organisasi, pada saat ini, dengan kondisi saat ini, menjadi sektor yang maju, jauh lebih maju dari hari ini, pada suatu ketika di masa depan, bahkan menjadi sektor yang terbaik dibanding sektor yang sama pada negara lain. Salah satu Menteri pada Kabinet Presiden Joko Widodo adalah Dr. Arief Yahya, Menteri Pariwisata. Meskipun kementeriannya adalah kementerian -eselon 3\|, meskipun pariwisata hanya sebagai -urusan pilihanl bagi Pemerintah Daerah, meskipun dengan anggaran yang terbatas, selama tiga tahun terakhir (2014 - 2017) prestasi sektor pariwisata Indonesia melampaui Malaysia, meski masih di bawah Thailand. Bahkan, pada tahun 2018, diperkirakan devisa dari sektor pariwisata menjadi yang terbesar dibanding CPO dan migas ${ }^{3}$.

\footnotetext{
${ }^{2}$ Mereka adalah, Dr. Soekarwo, Gubernur Jawa Timur, Ahmad Heriawan, Gubernur Jawa Barat, Syahrul Yasin Limpo, Gubernur Sulawesi Selatan, Irwan Prayitno, Gubernur Sumatera Barat dan TGH. M. Zainul Majdi, Gubernur NTB. Sementara 12 bupati yang meraih penghargaan yang sama antara lain, Abdullah Azwar Anas, Bupati Banyuwangi, Fadli, Bupati Lamongan, Aslam Patonangi, Bupati Pinrang, Sulsel, Nurdin Abdullah, Bupati Bantaeng, Sulsel, Sri Purnomo, Bupati Sleman, Hasto Wardoyo, Bupati Kulonprogo, Yuswir Arifin Dt. Indo Marajo, Bupati Sijunjung, Sumsel), Indra Catri, Msp Dt. Malako Nan Putiah, Bupati Agam, Kuryana Azis, Bupati Ogan Komering Ulu, Sumsel, Moh. Suhaili, Bupati Lombok Tengah dan Mardani H. Maming, Bupati Tanah Bumbu, Kalsel. Sedangkan untuk kategori wali kota yang mendapat penghargaan adalah, Tri Rismaharini, Wali Kota Surabaya, Ridwan Kamil, Wali Kota Bandung, H.Syaharie Ja'ang, Wali Kota Samarinda, Riza Falepi, Wali Kota Payakumbuh, Prana Putra Sohe, Wali Kota Lubuk Linggau, dan Sutarmadji, Wali Kota Pontianak, Rizal Effendi, Walikota Balikpapan.

${ }^{3}$ Melalui branding Wonderful Indonesia, peringkat pariwisata Indonesia di dunia meningkat ke peringkat 50 pada tahun 2015. Sebelumnya, di peringkat 70 dari 141 negara pada 2013. Bahkan, berdasarkan laporan resmi World Economic Forum, Indonesia berhasil melejit delapan peringkat hingga ke peringkat 42 pada 6 April 2017. Menteri mempunyai target, Indonesia akan mampu
} 
Bagaimana dengan Kementerian lain? Kementerian Pertanian mempunyai dua misi yang bersamaan: mencukupi pangan, khususnya beras, dan menyejahterakan petani. Indonesia selalu mengimpor beras mulai dari tahun 2000 hingga 2015 atau selama 15 tahun. Sementara, pada tahun 2016 sampai 2017 pemerintah berhenti sementara untuk mengimpor beras dan pada 2018 Indonesia kembali mengimpor beras 500.000 ton $^{4}$. Sementara itu, Nilai Tukar Petani (NTP) ${ }^{5}$ nasional berada di kisaran 103-104\%, yang berarti marjin usaha pertanian relatif rendah, sehingga sulit untuk menyejahterakan keluarga petani, apalagi petani yang sekedar buruh garap. Dalam pemahaman ilmu kebijakan publik, menteri di bidang pertanian belum dapat membangun kebijakan publik yang baik di sektornya.

mencapai ranking 20 sebelum 2019 dan bertekad pariwisata akan menjadi penghasil devisa negara terbesar sekaligus menjadi destinasi pariwisata terbaik di tingkat regional serta global. Sektor pariwisata diproyeksikan mampu menyumbang produk domestik bruto sebesar 15 persen, Rp 280 triliun untuk devisa negara, 20 juta kunjungan wisatwan mancanegara, 275 juta perjalanan wisatawan nusantara dan menyerap 13 juta tenaga kerja pada 2019. Sektor pariwisata diyakini mampu menciptakan pusat-pusat pertumbuhan ekonomi yang lebih tersebar di seluruh negeri ini. Diharapkan pula mampu memutus rantai kemiskinan, pengangguran, juga kesenjangan dengan cepat dan tepat. Pada tahun 2016 melalui branding Wonderful Indonesia, pariwisata Indonesia meraih 46 penghargaan dari 22 negara penyelenggara. Bahkan, Pavilion Wonderful Indonesia sukses mempertahankan gelar The Best Exhibition 2017. Tercatat pada semester satu 2017, parwisata Indonesia telah meraih 17 penghargaan. Penghargaan tersebut menandakan bahwa Indonesia memiliki potensi pariwisata yang sudah diakui banyak negara, sebagai tempat berlibur yang aman dan nyaman. Hal ini pun mempengaruhi pula pertumbuhan pariwisata di semester satu 2017 sebesar 22,4 persen. Saat ini pesaing bukan lagi Malaysia, Singapura, atau Thailand, yang pertumbuhannya masih di bawah 5 persen. Pesaing yang paling mendekati adalah Vietnam yang menjadi investor /darling. Berdasarkan laporan Telegraph.co.uk, hanya Indonesia dan Vietnam yang mewakili ASEAN dengan pertumbuhan hingga 25 persen dan masuk kategori Top-20 Fastest Growing Travel Destinations in the World. Pada kancah internasional, destinasi wisata tanah air telah meraih sejumlah penghargaan. Misalnya, Bali yang selama ini menjadi ikon pariwisisata dunia, terpilih sebagai destinasi pariwisata terbaik dunia versi Trip Advisor, mengalahkan London yang berada di peringkat kedua dan Paris di peringkat ketiga. Kebijakan yang diandalkan adalah menjadikan pariwisata sebagai sektor unggulan, dan berhasil dicapai semenjak Presiden Joko Widodo telah menetapkan pariwisata sebagai sektor unggulan pembangunan nasional, dan Pariwisata dijadikan sebagai salah satu core economy bagi negara ini ke depannya. Pada tahun 2007, jumlah wisman yang datang ke Indonesia 5,51 juta. Pada tahun 2013 kunjungan wisman mencapai 8,8 juta. Pada tahun 2017 jumlah wisman yang berkunjung ke Indonesia menjadi 14,04 juta. Pada tahun 2020, ditargetkan kunjungan wisman 20 juta. Pada tahun 2013, pendapatan devisa dari pariwisata mencapai US\$10,05 milyar. Pada tahun Pada 2015, devisa dari sektor pariwisata sebesar US\$12,225 miliar atau berada di posisi keempat di bawah Migas US\$

18,574 miliar, CPO US\$ 16,427 miliar, dan batu bara US\$14,717 miliar. Pada tahun 2016 mencapai US\$13,568 miliar berada di posisi kedua setelah CPO US\$15,965 miliar. Pada tahun 2017 yang sekitar US\$16,8 miliar, tetap nomor dua setekah CPO. Pada tahun 2018 diperkirakan mencapai US\$ 20 miliar, yang berarti pariwisata akan menjadi penghasil devisa terbesar. peningkatan devisa tersebut berasal dari target 17 juta wisatawan mancanegara yang tahun 2018 tumbuh 22\% dari tahun 2017.

\footnotetext{
${ }^{4}$ Selama 15 tahun tersebut, Indonesia telah mengimpor beras sebanyak 15,39 juta ton beras dengan volume impor beras terbanyak pada tahun 2011 dengan volume sebesar 2,75 ton, sedangkan volume terkecil pada tahun 2005 sebesar 189.616 ton. Sehingga, dengan jumlah total impor beras tersebut dan ditambah 500.000 ton pada tahun ini, maka hingga saat ini Indonesia telah mengimpor beras sebesar 15,89 juta ton. Sementara, dari sisi dana yang dikeluarkan pada impor beras sebesar 15,39 juta ton mencapai 5,83 miliar dollar AS atau Rp 78,70 triliun (kurs Rp 13.500). Baca juga : DPR Soroti Impor Beras Dana yang paling banyak dikeluarkan pada impor tahun 2011 dengan 1,51 milar dollar AS atau Rp 20,38 trilun, sedangkan dana yang paling dikeluarkan paling sedikit tahun 2005 dengan nilai 51,49 juta dollar AS atau Rp 695,1 miliar Kompas.com dengan judul "Begini Perjalanan Impor Beras Indonesia Sejak $\quad$ Tahun 2000 hingga 2018", https://ekonomi.kompas.com/read/2018/01/16/161052826/begini-perialanan-impor-beras-indonesia-sejak-tahun-2000hingga-2018.

Penulis : Achmad Fauzi

${ }^{5}$ NTP adalah perbandingan indeks harga yang diterima petani (It) terhadap indeks harga yang dibayar petani (Ib). - NTP merupakan salah satu indikator untuk melihat tingkat kemampuan/daya beli petani di perdesaan. NTP juga menunjukkan daya tukar (terms of trade) dari produk pertanian dengan barang dan jasa yang dikonsumsi maupun untuk biaya produksi. Semakin tinggi NTP, secara relatif semakin kuat pula tingkat kemampuan/daya beli petani
} 
Bagaimana dengan Presiden atau Perdana Menteri? Sama. Presiden atau PM menjadikan kebijakan publik sebagai strategi untuk mengalokasikan sumberdaya penting dan terbatas agar totalitas sektor dan kewilayaan di negaranya terangkat di atas rerata, dan menjadikannya sebagai sektor dan kewilayahan terbaik dibandingkan negara yang setara. Indonesia memang banyak dipuji sebagai negara dengan ekonomi terbesar di kawasan, sehingga menjadi anggota dari G-20. Namun, secara rerata, baik secara sektor maupun kewilayahan masih mengalami kendala yang akut. Dari perspektif ilmu kebijakan publik, Presiden Indonesia mengalami kendala dalam menjadikan kebijakan publiknya sebagai strategi yang efektif dan substansial untuk -mengungkitl kualitas kehidupan bangsa. Tentu saja, masalahnya tidak serta-merta berkenaan dengan Presiden, tetapi juga tim kerja, kondisi lingkungan domestik dan global yang kurang menguntungkan, juga karena -warisan\| kebijakan di masa lalu yang menjadi masalah besar pada hari ini.

Jika kebijakan publik adalah keputusan dan juga strategi, maka siapa yang sebenarnya aktor paling penting dalam kebijakan publik? Pertama, pemimpin. Dalam perjalanan mendampingi lembaga pemerintahan di Indonesia dan sejumlah negara sahabat di Asia, kawasan Pasifik, Eropa, dan Sub-Sahara, saya menemukan bahwa dalam membangun keberhasilan kebijakan publik, pemimpin menentukan. Leader matter! Tanpa kecuali. Tanpa Lee Kuan Yew, Singapura sangat mungkin tidak seperti sekarang ini. Demikian juga Malaysia tanpa Mahathir Mohammad yang kini comeback menjadi Pimpinan Malaysia. China termasuk yang paling berhasil, karena mempunyai Pimpinan Nasional dengan kecakapan dan prestasi yang berterusan: Deng Xiaping, sebagai Pemimpin tertinngi RRC pada tahun 70an hingga 90an, dilanjutkan dengan Jiang Jemin, Hu Jintao, dan Xi Jinping. Indonesia memiliki Soeharto, yang sempat membawa Indonesia memasuki keemasan di awal tahun 1990an, namun mengalami kemerosotan pada akhir 1990an, dan sempat mengalami rebound beberapa saat di bawah Presiden Habibie dan kemudian Bambang Yudhoyono pada periode pertama, kemudian terkendala dalam menciptakan suksesi kepemimpinan yang memadai. Presiden Jokowi berusaha keras, dan terus bekerja keras, meski mengalami kendala yang berat. Jadi, dalam membangun kebijakan publik, aktor pertama yang menjadi perhatian adalah Pemimpin, khususnya Pemimpin Puncak, baik di Pemerintahan, Kementerian, hingga Pemerintahan Daerah. Karena itu, mempelajari kebijakan publik menjadi sebuah keharusan bagi setiap Pemimpin dan Calon Pemimpin. Karena, sehebat 
apa pun gagasan kenegaraan, ketika Pemimpinan gagal memimpin upaya membangun kebijakan publik untuk merealisasikan gagasan tersebut, maka gagasan akan terpulang sebagai gagasan; rakyat akan berada dalam kesendirian bersama angan-angan yang pernah dijanjikan kepada mereka. Pemimpin adalah aktor yang mempunyai peran memastikan hanya kebijakan-kebijakan unggul, yang mengunggulkan bangsa yang boleh dibuat, sementara yang lain tidak boleh dibuat. Pemimpin adalah policy (decision) maker.

Ke dua, analis kebijakan. Siapa yang membantu pemimpin dalam membuat/membangun kebijakan yang unggul? Pastilah analis kebijakan. Mereka adalah para intelektual, baik yang berada di dalam Pemerintahan, lembaga penelitian dan pengembangan keilmuan, para pengajar, dan lembaga pendampingan atau konsultan di bidang kebijakan publik, baik secara generik atau sebagai sebuah sektor. Ada tiga kendala yang muncul di Indonesia pada saat ini. Pertama, profesi analis kebijakan publik dianggap sebagai sebuah profesi administratif, bahkan profesi klerikal, sehingga pengembangan dan pembinaannya tidak sesuai dengan kebutuhan pengembangan dan pembinaan analis kebijakan. Ke dua, analis kebijakan di dalam Pemerintahan dan konsultannya cenderung menjadi justifikator atau stempel atas kemauan politik dan/atau birokrasi agar tidak membahayakan keberadaan mereka bahkan memberikan insentif yang baik. Ke tiga, pusat-pusat pengembangan birokrat senior $^{6}$ memberikan perhatian secara terbatas kepada pengembangan kebijakan publik unggul seperti yang diperlukan.

\section{Solusi}

Kebijakan politik harus benar, tidak cukup hanya baik. Artinya, ruang -errorll harus termamat sangat kecil, kalau bisa zero defect. Karena, kemelencengan $1 \%$ pada pembuat kebijakan, terjadi penyimpangan sekitar 1 sentimeter. Namun, pada sangat -di masyarakatl, maka penyimpangan terjadi bisa sampai 100 kilometer. Perspektif geometrikal perlu dimiliki oleh setiap aktor penting dalam kebijakan publik, oleh para penyiap dan pendamping kebijakan publik, dan oleh publik, warga masyarakat, untuk memastikan

kehidupan mereka bukan menjadi sebuah -pertaruhan-perjudian\| dari pemegang kekuasaan, melainkan sebagai suatu kehidupan yang berharga untuk dijalani, baik

\footnotetext{
${ }^{6}$ Kemendagri, KemenPan\&RB, Kemenhukham, Kemensetneg, Setwapres, LAN, hingga DPR, DPD, dan DPRD. LAN menghilangkan modul Kebijakan Publik sejak tahun 2011.
} 
sebagai manusia, komunitas, bangsa, maupun sebagai umat Tuhan. Kebijakan publik tidak boleh sia-sia dibuat, apalagi menyia-siakan manusia yang menjadi publiknya.

Kebijakan publik adalah -pertaruhan terbesarll setiap pemerintah. Mari kita simak pernyataan Prof. Michael Porter, Bishop William Lawrence University Professor at Harvard Business School (2006), sebagai berikut:

What makes government effective? This is among the most important question facing any society, because the failure of government is all too common and often catastrophic. There are numerous examples of countries that have been saddled by bad government policies, poor implementation, ethical failures, and the inability of government to change when it necessary. The victims are citizens, whose lives and livehoods suffer.

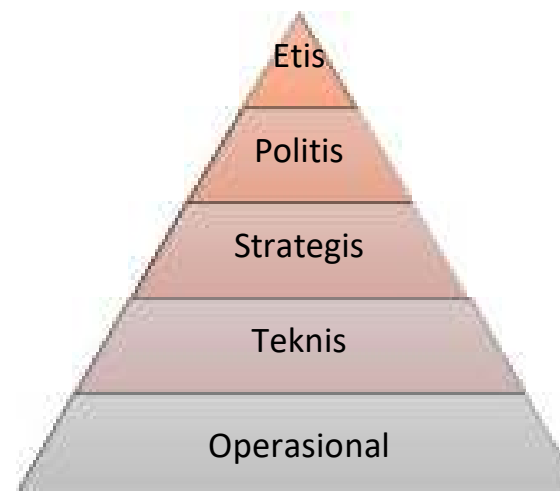

Kita telah sampai pada pemahaman bahwa menguasai kebijakan publik adalah keharusan bagi setiap penyelenggara negara. Ini sejalan dengan tiga premis yang saya kembangkan selama 15 tahun terakhir ${ }^{7}$. Pertama, keunggulan negara semakin ditentukan oleh seberapa mampu para pengelola negara membangun kebijakankebijakan unggul. Premis ke dua, adalah tidak peduli bagaimana negara, sistem politik ataupun kekayaan alamnya, sepanjang pemerintahnya dapat membangun kebijakankebijakan publik yang unggul, maka negara itu akan menjadi negara pemenang di antara negara-negara lain yang menjadi kolega maupun pesaingnya. Premis yang ke tiga, hanya dua tugas utama pemerintah, membangun kebijakan publik yang unggul dan memberikan pelayanan publik yang bermutu tinggi.

Dengan demikian, tugasnya adalah memperkuat dua aktor paling penting dalam membangun kebijakan publik unggul (excellence), pemimpin dan para calonnya, dan para analis kebijakan publik. Pertanyaannya adalah, bagaimana? Ini menjadi isu penting karena kebijakan publik banyak diajarkan secara sulit, ruwet, njlimet, menyebalkan, membosankan, dan bahkan diajarkan dengan keliru atau salah, baik dari cara maupun substansinya. Karena itu, berikut ini disampaikan metode yang dirasakan selama ini cukup membantu penguatan kapasitas most important actor dari kebijakan

\footnotetext{
7 Lihat Riant Nugroho, 2001, Reinventing Indonesia, Jakarta: Elex/Gramedia, Riant Nugroho, 2003, Reinventing Pembangunan, Jakarta: Elex/Gramedia, Riant Nugroho, 2003, Kebijakan Publik, Jakarta: Elex/Gramedia, Riant Nugroho, 2004, Analisis Kebijakan, Jakarta: Elex/Gramedia, Riant Nugroho, 2006, Kebijakan Publik Negara Berkembang, Jakarta: Elex/Gramedia, Riant Nugroho, 2016 (2008), Public Policy, Jakarta: Elex/Gramedia, Riant Nugroho, 2015, Kebijakan Publik di Indonesia, Yogjakarta: Pustaka Pelajar, Riant Nugroho, 2017, Policy Making, Jakarta: Elex/Gramedia.
} 
publik. Metode ini mengajarkan, bahwa ada lima jenjang penguasaan atas kebijakan publik, yaitu jenjang operasional, teknis, strategis, politis, dan etis.

Kita mulai dari tengah: strategis. Pada pemahaman strategis, kebijakan publik harus difahami sebagai sekuensi untuk mentransformasikan sumberdaya bangsa menjadi aset bangsa, dan

akhirnya menjadi keunggulan bangsa. Kebijakan publik adalah teknologi untuk merubahnya.

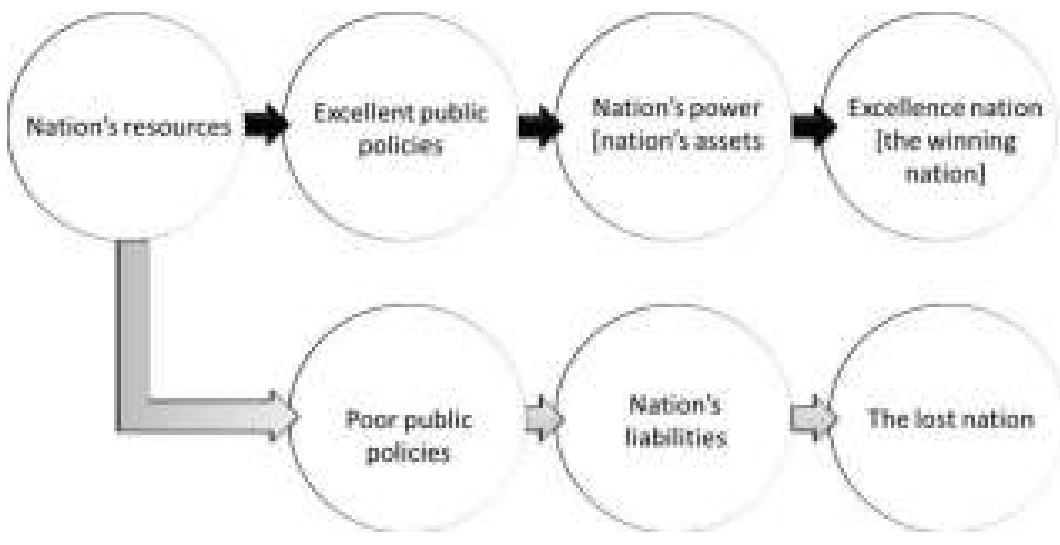

Disebut sebagai -teknologill, karena harus -ramah penggunall (user friendly) dan sesuai dengan kebutuhan yang dihadapi (tailored made). Kebijakan yang baik merubah sumberdaya menjadi aset.

Kebijakan yang buruk menjadikan sumberdaya menjadi beban, bahkan malapetaka. Dengan demian, tantangan strategis kebijakan publik adalah seberapa hebat kebijakan publik bisa mengungkit sumberdaya yang ada menjadi aset yang luar biasa.
Pemahaman
teknis.
Dalam pemahaman ini,
kebijakan publik difahami
sebagai sebuah proses
manajemen. Dengan demikian,
yang perlu disimak adalah
proses kebijakan publik.
Selama ini, kebijakan publik
diajarkan sebagai sebuah

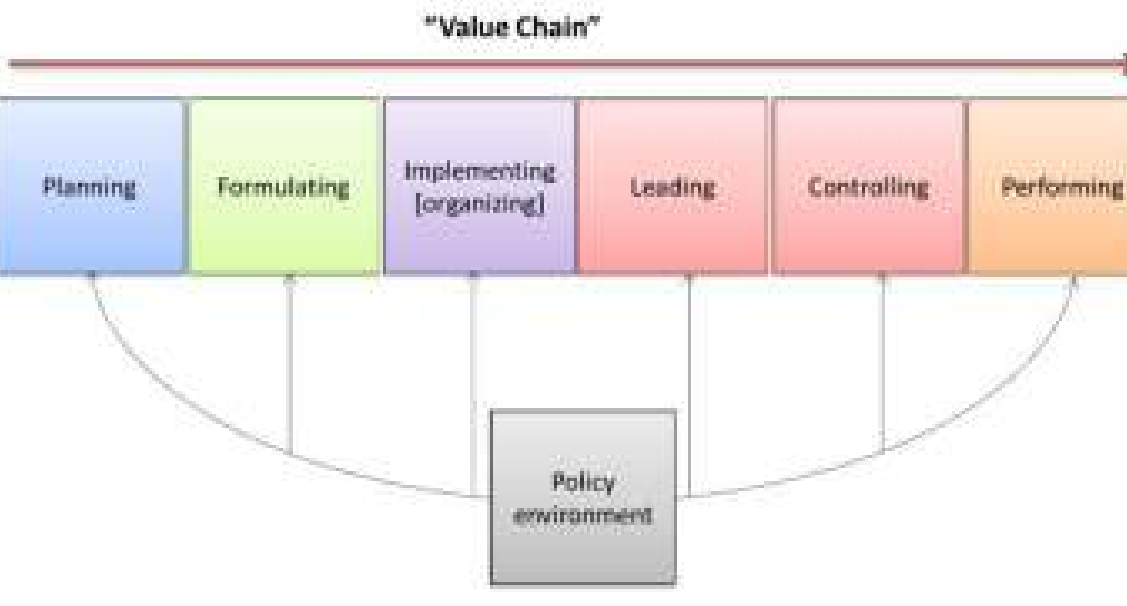
proses -perumusan-implementasi-evaluasill. Pada pemahaman ini, kebijakan publik perlu difahami sebagai sebuah fakta manajemen, yang berarti sekuensinya identik, atau setidaknya sebangun, dengan proses manajemen, yaitu: -perencanaan-perumusan- pelaksanaan/pengorganisasian-kepemimpinan-pengendalian\| yang bergerak dalam sebuah irama rantai nilai (value chain). Kebijakan publik harus direncanakan, tidak tiba-tiba dibuat. Perumusannya perlu mengikuti kaidah yang memadai. Pelaksanannya harus dimulai dari pengorganisasian dan kesiapan manusia pelaksana dan penerima. Harus ada pemimpin yang bertanggungjawab bila utuk mencapai keberhasilan, dan 
dapat dihukum apalbila terjadi kegagalan, dan ada pengendalian, yang terdiri dari monitoring-evaluasi-insentif ${ }^{8}$.

Pada pemahaman operasional, maka proses kebijakan publik dilihat sebagai sebuah turunan operasional dari suatu proses manajemen, dan disarankan untuk ditata dalam tujuh langkah yang diberi nama sebagai -The 7 Stepwise of Policy Process $\|$, sebagai berikut:



Secara proses pun harus difahami, bahwa kebijakan publik tidak serta-merta identik dengan hukum. Proses kebijakan publik yang serta-merta identik dengan hukum biasanya terjebak kepada perdebatan kering pasal-demi-pasal, dan pada akhirnya terjadi -kompromi pasall. Kebijakan publik terdiri dari kebijakan formal, konvensi, ucapan pejabat publik, dan perilaku pejabat publik. Hukum adalah salah satu bentuk kebijakan formal. Kebijakan publik mempunyai dua paradigma, kontinentalis, yang hukumminded, top-down, tidak lengkap, fokus pada tata cara, dan anglo-saxonis yang fokus kepada interaksi publik-negara, lengkap, dan fokus kepada substansi. Kebijakan publik pun tidak serta-merta diawali dari -masalah\|, melainkan -isull, yang dapat berupa -masalah\| atau -gagasan masa depan\|. Dalam operasionalisasi, kebijakan publik

\footnotetext{
${ }^{8}$ Untuk diskusi lebih lanjut dapat disimak pada Nugroho, 2017, Policy Making, Jakarta: Elex/Gramedia.
} 
dimulai dari analisis kebijakan, yang tidak saja menjustifikasi, namun juga dapat memfalsifikasi suatu rencana kebijakan?

Pemahaman selanjutnya adalah, politis -atau juga ideologis. Pemahaman kebijakan publik dalam dimensi politis mengamanatkan kepada pembuat kebijakan dan analis kebijakan untuk senantiasa -mengembalikan\| kebijakan publik yang disiapkannya kepada ideologi bangsa, di mana untuk Indonesia adalah Pancasila. Apabila kebijakan publik sesuai dengan Ketuhanan Yang Maha Esa, Kemanusiaan yang adil dan beradab, Persatuan Indonesia, Kerakyatan yang dipimpin oleh hikmat kebijaksanaan dan permusyawaratan/perwakilan, dan

Keadilan sosial bagi seluruh rakyat Indonesia, sudah dilalui, maka kebijakan tersebut -lulus\| dalam ujian politik. Sila-sila Pancasila perlu difahami sebagai seperangkat nilai bukan hanya kata-kata. Misalnya, selama ada Pancasila, maka selama itu tidak dibolehkan kebijakan yang mengatas-namakan (penganut) agama tertentu yang mengalahkan (penganut) agama lain. Kementerian Pariwisata, misalnya, mengedepankan Promosi Pariwisata Halal/Syariah, namun tidak mengijinkan adanya Peraturan Pariwisata Halal/Syariah. Sayangnya, ada pemerintah daerah yang menetapkan perda tentang pariwisata syariah. Kebijakan tax amnesty yang akhirnya dilaksanakan tanpa pandang bulu, pun dapat dinilai bertentangan dengan sila ke lima Pancasila. Pada prinsipnya, kebijakan publik yang kepentingan-kepentingan apa pun, sepanjang tidak bertentangan dengan kepentingan nasional, yang ada pada Pancasila, boleh dibuat dan dikembangkan seluas-luasnya. Pancasila adalah yang pertama dan utama, bahkan -di atasll pasal-pasal pada UUD 1945.

Kebijakan publik mengatur, mengarahkan, dan mengembangkan interaksi di dalam komunitas, dan antara komunitas dengan lingkungannya, untuk kepentingan agar komunitas tersebut dapat memperoleh atau mencapai kebaikan yang diharapkannya secara efektif. Kebijakan publik adalah alat (tool) dari suatu komunitas yang melembaga untuk mencapai social beliefs about goodness-nya. Keberhasilkan dan/atau kegagalan kebijakan publik dalam mencapai goodnesss secara

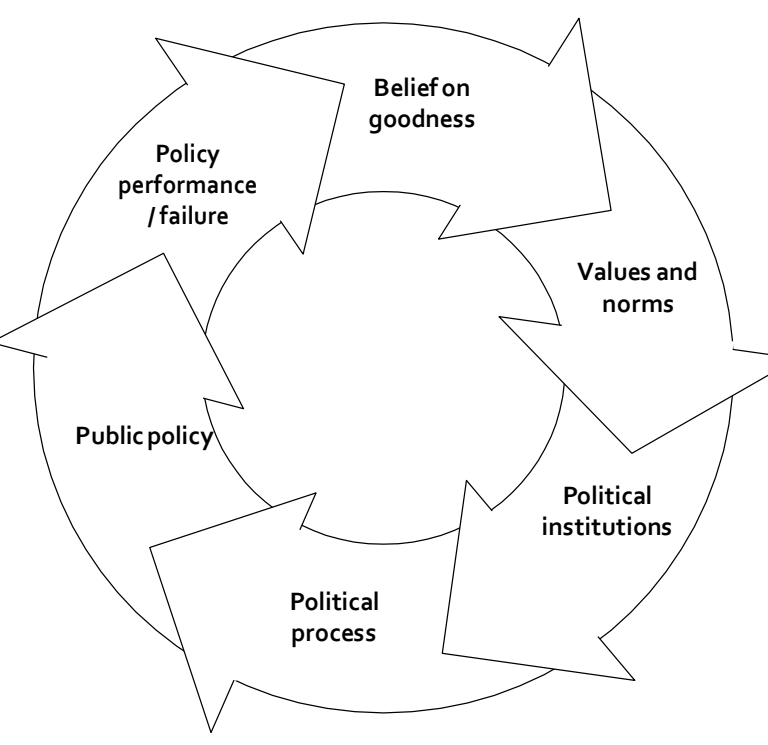
${ }^{9}$ Untuk diskusi lebih lanjut lihat Nugroho, 2017, Policy Making, Jakarta: Elex/Gramedia; dan Nugroho, 2016, Public Policy, Jakarta:
Elex/Gramedia 
efektif akan melahirkan kepercayaan sosial baru. Di satu sisi, keberhasilan kebijakan publik akan memperkuat (strengthening) kepercayaan sosial yang dipegang, di sisi lain kegagalan kebijakan publik akan melemahkan, bahkan dapat meruntuhkan, keyakinan sosial yang ada. Pertanyaan penting di sini adalah, apa belief on goodness dari Negara Kesatuan Republik Indonesia? Jelas: Pancasila, dan baru disusul UUD 1945. Inilah yang disebut sebagai the principle-centered public policies paradigm.

Akhirnya, pemahaman etis. Kebijakan publik adalah masalah pilihan-pilihan dilematis, dan pilihan tersebut sebagian besar -kalau tidak seluruhnya —ada pada ranah etis. Kita mulai dari isu pertama: kekuasaan. Pimpinan puncak adalah pemegang kekuasaan, dan -kekuasaan adalah Jubah Tuhanll. Artinya, pemimpin puncak tidak boleh menyalahgunakan kekuasaan, atau -Jubah Tuhan\| yang sedang -dipinjamkan\| kepadanya, termasuk di dalamnya sewenang-wenang ${ }^{10}$ dan menyia-siakan ${ }^{11}$ kekuasaan. Bentuk paling buruk adalah membuat kebijakan publik yang memburukkan kehidupan rakyat, bahkan kehidupan umat manusia. Di tingkat nasional, kebijakan yang menciptakan sengketa di kawasan Asia Selatan dan Afrika bagian tengah, yang menyengsarakan rakyat masing-masing.

Di tingkat global, sengketa negara adikusa dengan kepentingannya secara sengaja ataupun tidak, menciptakan kerusuhan tanpa henti di kawasan Siria, serta di sisi lain muncul gerakan klandestin global ISIS. Di tingkat paling mikro, seorang pejabat tinggi di sebuah Pemerintah Daerah membuat kebijakan yang sudah diketahuinya tidak baik (dan tidak benar

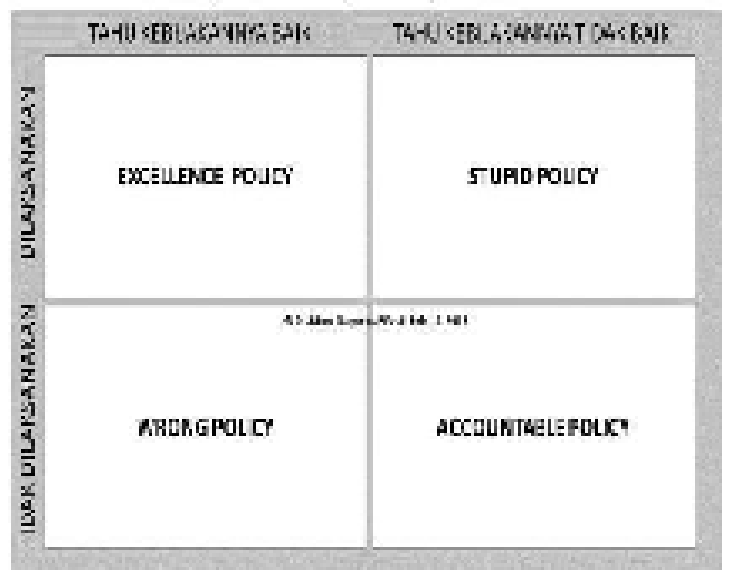
juga), tetapi tetap dilaksanakannya; sebuah kenyataan yang sering kita ledek sebagai -stupid policyll. Karena kebijakan publik adalah masalah moral, masalah etikal, maka pembelajaran penting dari para pimpinan dan calon pimpinan, dan para analis kebijakan adalah, apakah mereka sudah menyelesaikan dilema etik atau moral, ataukah belum. Jika dilema etikal sudah selesai, maka mereka boleh melanjutkannya.

Pertanyannya, bagaimana menyelesaikan dilema moral, yang berujung pada pertanyaan -to do or not to do?\| Solusinya adalah, kembalikan kepada

\footnotetext{
${ }^{10}$ Artinya bertindak di luar wenenang

${ }^{11}$ Artinya membuat tidak berarti kekuasaan itu
} 
pertanggungjawaban moral, untuk siapa sebenarnya kebijakan ini dibuat? Matriks berikut ini barangkali dapat membantu kita:

\begin{tabular}{|l|l|}
\hline \multicolumn{1}{|c|}{$\begin{array}{c}\text { Untuk siapa sebenarnya kebijakan } \\
\text { dibuat }\end{array}$} & \multicolumn{1}{c|}{ Tindakan disarankan } \\
\hline Vendor & Stop \\
\hline Pendonor waktu Pemilu & Stop \\
\hline Kelanggengan kekuasaan & Stop \\
\hline Keluarga & Cek \\
\hline Partai & Hati-hati, pelajari dengan baik \\
\hline Organisasi/Lembaga & OK, tetapi harus cermat \\
\hline Pimpinan & OK, tetapi harus cermat dan \\
profesional \\
\hline Rakyat & OK, kerjakan secara profesional \\
\hline (Kemuliaan) Tuhan ${ }^{12}$ & Sangat OK .... \\
\hline
\end{tabular}

\section{Catatan Akhir}

Dalam perjalanan waktu, saya melihat sangat banyak -the alchemy of policy $\|^{13}$, kebijakan yang -ajaib\|, dibuat dengan berhasil, dilaksanakan berhasil, hasilnya pun berhasil. Di Indonesia setidaknya ada beberapa kebijakan yang dinilai masuk kategori tersebut, kebijakan keluarga berencana, kebijakan kelompok-kelompok pertanian, kebijakan karang taruna, kebijakan pendidikan gratis di Jembrana, kebijakan lahir ceprot dapat akte di Banyuwangi, kebijakan SIM-Corner di Surabaya, kebijakan patenisasi produk UMKM di Jawa Timur, dan kebijakan pertanian di Kulon Progo. Di Singapura kita melihat kebijakan public transport yang sangat baik. Di Malaysia kita melihat kebijakan stabiliasi krisis pada tahun 1998 yang dipimpin oleh PM Mahathir. Di China kita melihat -geliat dan sabetan Nagall yang membuatnya menjadi negara yang menggentarkan. Lihat saja rencananya untuk membangun jaringan transportasi Beijing London, hingga dukungan informal untuk membuka -Selat Krall. Di Rusia, Putin, menjadikan migas sebagai kekuatan negara, bukan sebagai ajang kekayaan pemilik usaha kerajaan-kerajaan migas dunia. Korea menjadikan K-Pop sebagai hentakan kultural yang melanda dunia.

\footnotetext{
${ }^{12}$ Kemuliaan Tuhan, bukan agama

${ }^{13}$ Disampaikan pada Pertemuan ke X International Conference of Public Administration, Chengdu, PR China, 2014.
} 
Pertanyannya adalah, mengapa bisa? Ini pertanyaan penting bagi semua Kepala Pemerintahan di Indonesia, sebagaimana di ASEAN dan sekelilingnya. Keberhasilan Pemerintah menentukan keberhasilan negara. Keberhasilan negara memastikan keberhasilan bangsa. Kembali ke Prof. Porter, keberhasilan pemerintah ditentukan keberhasilannya membangun excellence policies. Tantangan kita adalah, kenyataan yang acapkali pahit, para Pimpinan tidak (mau) mengerti, bahwa kebijakan publik adalah agenda utama dan pertama.

Cukup banyak kasus yang menunjukkan, sebagian (besar) para pimpinan kita banyak mengucapkan KEBIJAKAN PUBLIK tetapi belum cukup memahami apa makna KEBIJAKAN PUBLIK. Karena tidak memahami dengan cukup, maka mereka menjadikan kebijakan publik sebagai tugas bawahan mereka, dan jika pun dikerjakan hanya tugas sampingan dari mereka sendiri. Tugas utama dari pemimpin pemerintahan yang dipilih adalah tugas -Seremonial, Memberi pengarahan, Pencitraan diri, Administratif, dan Hobill. Jadi, catatan akhirnya adalah agar semua Pimpinan Pemerintah menjadi Master Kebijakan Publik.

Untuk memulai penguatan para pimpinan pemerintahan agar -bersediall belajar (dan menjadi master) kebijakan publik adalah dengan mencermati dan mengingat 10 Prinsip Utama (bisa juga disebut -Hukum\|) Kebijakan Publik, yaitu:

Prinsip 1 : Publik. Kebijakan publik adalah kebijakan untuk publik, sehingga sejak awal meletakkan unsur Kepentingan Publik di atas kepentingan lainnya, termasuk kepentingan bisnis dan kepentingan politik baik orang-seorang atau golongan atau organisasi tertentu. Karena itu, kebijakan publik harus menaruh prinsip kolaborasi dan empati kepada publik, sejak dari dimensi formal, kognitif, hingga nilai. Pertanyaan: di mana letak -publik\|l di dalam kebijakan publik kita?

Prinsip 2 : A Point of No Return. Kebijakan publik adalah keputusan pemerintah yang tidak dapat ditarik kembali, sehingga harus dibuat dengan serius dan sungguh-sungguh. Pertanyaan: berapa banyak dan berapa kali kita membuat kebijakan terus kita tarik kembali?

Prinsip 3 : Great, not Good. Kebijakan publik adalah keputusan yang hebat, dan bukan sekedar baik. Tujuannya tidak sekedar membaikkan bangsa tetapi menghebatkan bangsa. Karena itu harus dibuat oleh orang-orang terbaik dengan cara-cara terbaik. Tidak boleh dikerjakan oleh sembarang orang dengan sembarang cara. Sudahkah kita mengambil best people dan best method dalam kita membuat kebijakan publik? 
Prinsip 4 : Manajemen, bukan politik. Kebijakan publik adalah keputusan manajemen, karena tugasnya adalah untuk mengkreasikan nilai dari semua aset yang ada dan yang mungkin ada untuk semuanya. Bukan keputusan memperbutkan aset untuk dikuasai kelompok tertentu, seperti prinsip politik Laswell who get what... Kebijakan publik adalah manajemen, sehingga tidak cukup hanya dengan proses formulatingimplementing-evaluating, namun planning-formulating-implementing- leadingcontrolling. Pertanyaan: sudahkah manajemen lebih banyak menjadi roh, ataukah lebih banyak politik?

Prinsip 5 : Masalah moral, bukan teknis. Kebijakan publik pada awal dan akhir adalah tentang Moralitas Pemerintah, bukan tentang masalah-masalah teknis. Pertanyaan: sudahkah kita meletakkan dasar-dasar moral di dalam kebijakan kita daripada dasar-dasar formal -yang harus ada sesuai dengan peraturan?

Prinsip 6 : Sebuah sistem, bukan satuan-satuan. Kebijakan publik adalah sebuah sistem dari kebijakan-kebijakan publik. Sistem ini akan menjadi unggul jika berhasil menjadi sebuah entitas kebijakan publik nasional yang terdiri dari kebijakan-kebijakan publik sektoral dan regional yang unggul, saling melengkapi, saling mendukung, dan saling mengukuhkan. Pertanyaan: sudahkah kebijakan-kebijakan publik kita saling bersinergi daripada saling bertabrakan?

Prinsip 7 : Sebuah hadiah. Kebijakan publik adalah sebuah hadiah dari Pemerintah untuk rakyatnya. Karena hadiah, haruslah memberikan kebahagiaan, dan bukannya kesedihan. Kebijakan yang menyedihkan rakyat adalah kebijakan yang terburuk yang pernah ada. Pertanyaan: sudahkah kebijakan publik kita menjadi hadiah daripada musibah? Prinsip 8 : Kehormatan. Kebijakan publik adalah kehormatan untuk Pemerintah, dan bukannya tugas. Sebagai sebuah kehormatan, sudah pasti dilakukan dengan cara-cara yang terhormat dan menghasilkan praktik-praktik yang terhormat. Pertanyaan: sudahkah kita merasakan bahwa itu adalah kehormatan daripada tugas dan wewenang? Prinsip 9 : Memuliakan. Kebijakan publik adalah untuk memuliakan rakyat, bukan untuk menghukum. Kebijakan publik muncul ketika negara berubah dari negara ketertiban ke negara kesejahteraan. Jika negara ketertiban cukup diatur oleh hukum, maka kesejahteraan tidak dapat dicapai dengan hukum, melainkan dengan kebijakan publik. Pertanyaan: sudahkah kita mengerti bahwa kita memerlukan kebijakan publik, daripada hukum semata? 
Prinsip 10 : Pembelajaran. Kebijakan publik adalah pembelajaran yang baik bagi suatu bangsa untuk hidup lebih baik dari hari lalu dan hari ini. Pertanyaan: sudahkah kebijakan publik kita memberi pembelajaran yang baik kepada bangsa kita?

Jika di depan kita, bagaimana kebijakan publik di era demokrasi, dan kebijakan publik yang bagaimana yang perlu kita bangun pada era demokrasi, untuk memperkuat demokrasi, membuat demokrasi semakin sehat dan bernilai bagi bangsa? Tulisan ini merupakan perjalanan untuk menemukenali cara bagaimana agar Pemerintah di negara demokratis di negara berkembang dapat menjadi pembuat dan pengembang kebijakan-kebijakan publik unggul. Diskusi kita memberikan jawaban sebagai berikut:

-Di dalam praktek, setidaknya ada lima jenis demokrasi: productive democracy, yaitu demokrasi yang menghasilkan nilai bagi bangsa, constructive democracy, demokrasi yang mampu menkonstruksikan, membentuk bangsa, menjadi bangsa yang (menuju) demokrasi, accomodative

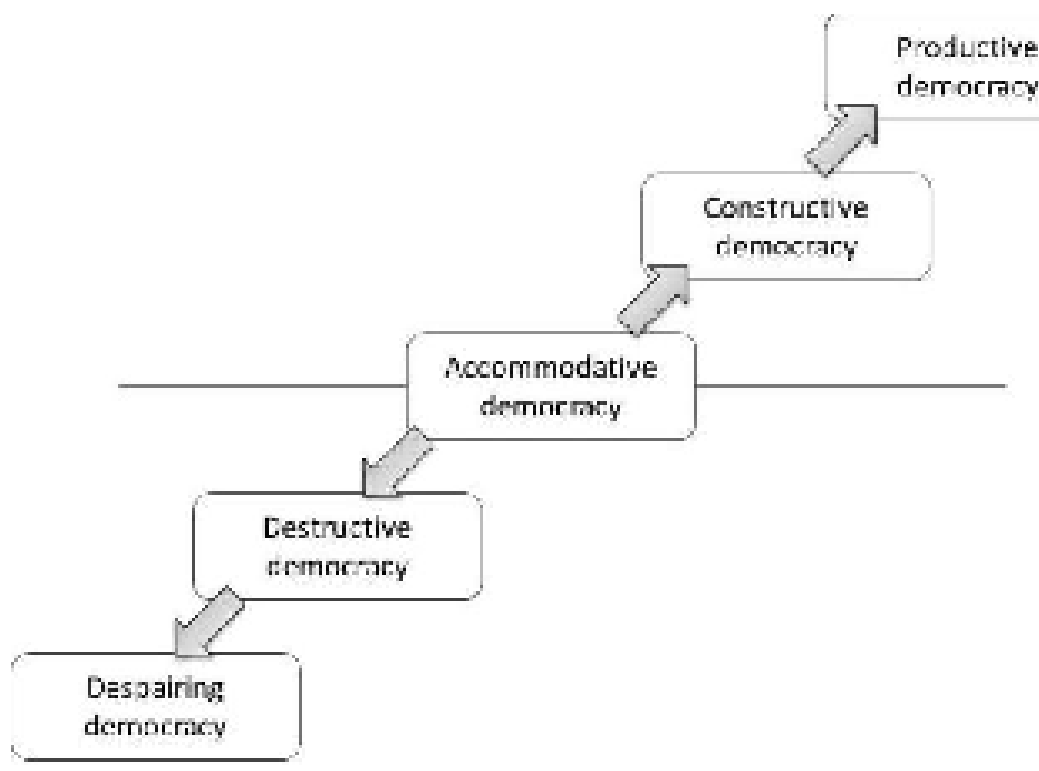
democracy, demokrasi yang menampung segala aspirasi, -demokrasi pelangill, destructive democracy, demokrasi yang meruntuhkan sendi-sendi kehidupan berbangsa, dan despairing democracy, demokrasi yang mengecewakan. Pertanyaan kita adalah, apa ukuran untuk mempunyai productive democracy? Jawabannya adalah demokrasi yang prosesnya dapat men-deliver kebijakan-kebijakan publik unggul. Diskusi di depan, hingga kita berbicara tentang 10 Prinsip', adalah cara agar demokrasi kita menjadi demokrasi yang menghasilkan. The Productive democracyl. 


\section{Daftar Pustaka}

Acemoglu, D, Robinson, J.A., 2012, Why Nations Fail: The Origins of Power, Prosperity, and Poverty, New York: Crown Business/Random House

Acemoglu, D, Robinson, J.A., 2019, The Narrow Corridor: States, Societies, and the Fate of Liberty, New York: Penguin Random House

Agamben, G., 2005, State of Exception, Chicago: The University of Chicago Press

Allison, G., dkk, 2013, Lee Kuan Yew: The Grand Master's Insights on China, United States, and the World, Massachusetts: MIT Press

Ambardi, K., 2009, Mengungkap Politik Kartel: Studi tentang Sistem Kepartaian di Indonesia Era Reformasi, Jakarta: Kepustakaan Populer Gramedia

Aristoteles, 2017, Politik (terjemahan) Yogyakarta : Narasi.

Breman, I, 2006, The J Curve: A New Way to Understand Why Nations Rise and Fall, New York: Simon \& Schuster.

Budiardjo, M. 2008, Dasar-Dasar Ilmu Politik, Jakarta : Gramedia Pustaka, h. 107.

Feith, H., 1984, "Rezim-rezim Developmentalis Represif di Asia: Kekuatan Lama, Kerawanan Baru, Prisma, 9 (11).

Freeland, C., 2012, Plutocrats: The Rise of the New Global Super Rich and the Fall of Everyone Else is a book about economic inequality, New York: Penguin

Habermas, J., 2010, Ruang Publik, Sebuah Kajian Tentang Kategori Masyarakat Borjuis (terj.). Bantul: Kreasi Wacana.

Huntington, S.P, 1968, Political Order in Changing Societies, Yale: Yale University Press. Levitsky, S, Ziblatt, D., 2018, How Democracies Die, New York: Penguin Random House Mulgan, G., 1994, Politics in an Antipolitical Age, London: Polity Press

Nugroho, R., 2013, Policy Making, Elex: Gramedia. Lihat juga Talcott Parsons, 1967, The Structure of Social Action, New York: Free Press

Nugroho, R., 2008, Public Policy (edisi pertama), Jakarta: Elex/Gramedia.

Nugroho, R., 2022, Tugas Pemerintah, Jakarta: Elex/Gramedia.

Schwab, K., 2016, The Fourth Industrial Revolution, Geneva: World Economic Forum.

Sumarto, M., 2018, Perlindungan Sosial dan Klientelisme: Makna Politik Bantuan Tunai dalam Pemilihan Umum Sosial \& Politik, Yogjakarta: UGM Press.

Sumption, J., 2019, Trials of the State, London: Profile Books 